\begin{tabular}{|c|c|c|}
\hline $\begin{array}{l}\frac{ \pm}{ \pm} \\
\frac{ \pm}{\frac{2}{n}}\end{array}$ & keberdonivitan & $\begin{array}{l}\text { Keberlanjutan : Jurnal Manajemen dan Jurnal } \\
\text { Akuntansi } \\
\text { http://openjournal.unpam.ac.id/index.php/keberlanjutan/index } \\
\text { Volume } 5 \text { (2) } 2020,142-156\end{array}$ \\
\hline
\end{tabular}

\title{
Standalone Report, Assurance Report, GRI Reporting Framework dan Kualitas Pengungkapan Sustainability Report
}

\author{
Huda Trihatmoko, Sri Ningsih ${ }^{2}$, Muhammad Raihan Mubaraq ${ }^{3}$ \\ ${ }^{123}$ Universitas Airlangga, Indonesia
}

\section{Email Penulis :}

hudatrihatmoko@yahoo.com ${ }^{1}$ sri.ningsih@feb.unail.ac.id ${ }^{2}$ mraihanmubaraq@gmail.com ${ }^{3}$

\section{Article Info}

Article history:

Received: 2020-09-29

Accepted: 2020-12-14

Published: 2020-12-15

Kata Kunci: Standalone Report, Assurance Report, GRI Reporting Framework, Sustainability Report

\begin{abstract}
The purpose of this study was to examine the effect of a standalone report, assurance report, and GRI reporting framework on the quality of sustainability report disclosure in companies listed on the Indonesia Stock Exchange in 2016-2018. Measurement of the quality index of the sustainability report disclosure in identifying the item or content of the analysis uses the total quality score of the sustainability report disclosure for each company compared to the absolute maximum disclosure score. The standalone report, assurance report, and GRI reporting framework measurement uses a dummy: 1 if it owns the component and 0 if it does not. The sample of this research is 145 companies selected by purposive sampling method. The results of this study indicate that the standalone report and the assurance report do not affect. Still, the GRI reporting framework has a significant positive effect on the quality of sustainability report disclosure.
\end{abstract}

\begin{abstract}
Abstrak
Tujuan penelitian ini adalah untuk menguji pengaruh standalone report, assurance report dan GRI reporting framework terhadap kualitas pengungkapan sustainability report pada perusahaan yang terdaftar di Bursa Efek Indonesia tahun 2016-2018. Pengukuran indeks kualitas pengungkapan sustainability report dalam mengidentifikasi item atau isi analisis menggunakan total skor kualitas pengungkapan sustainability report untuk masing-masing perusahaan dibandingkan dengan total skor pengungkapan maksimum. Pengukuran standalone report, assurance report dan GRI reporting framework menggunakan dummy, yaitu 1 jika perusahaan memiliki komponen, dan 0 jika tidak. Sampel penelitian ini adalah 145 perusahaan yang dipilih dengan metode purposive sampling. Hasil penelitian ini menunjukkan bahwa standalone report dan assurance report tidak berpengaruh, namun GRI reporting framework berpengaruh positif terhadap kualitas pengungkapan sustainability report.
\end{abstract}

Cara Mengutip :

Trihatmoko, H. Ningsih, S., \& Mubaraq, M.R. (2020). Standalone Report, Assurance Report, GRI Reporting Framework dan Kualitas Pengungkapan Sustainability Report. Keberlanjutan : Jurnal Manajemen dan Jurnal Akuntansi, 5(2), 142-156

Trihatmoko / Keberlanjutan : Jurnal Manajemen dan Jurnal Akuntansi, 5 (2) 2020, 142-156.
ISSN : 2614-3291 (online) http://dx.doi.org/10.32493/keberlanjutan.v5i2.y2020.p142-156 


\section{PENDAHULUAN}

Sustainability report adalah topik penting yang banyak dibahas dan diteliti dalam bisnis dan ekonomi. Dewan bisnis dunia untuk pembangunan berkelanjutan mendefinisikan sustainability report sebagai tanggung jawab bisnis kepada karyawan, keluarga mereka, komunitas lokal, dan masyarakat luas untuk bekerja sama meningkatkan kualitas hidup mereka dan berkontribusi pada pembangunan ekonomi berkelanjutan (Ansell \& Gash, 2008). Singkatnya, sustainability report merujuk pada kebijakan perusahaan terhadap dampak lingkungan yang dihasilkan. Di beberapa negara, tanggung jawab perusahaan atau pelaporan keberlanjutan kini menjadi bagian tak terpisahkan dari laporan tahunan perusahaan, dan jumlah perusahaan yang mengeluarkan laporan keberlanjutan yang berdiri sendiri meningkat.

Sustainability report sendiri merupakan isu yang berkembang yang banyak berpengaruh terhadap perusahaan domestik dan internasional. Penyebab fenomena ini adalah tren perkembangan praktik sustainability report diperusahaan. Menurut Dewi \& Keni (2016) banyak organisasi yang tertarik untuk melakukan kegiatan pelaporan keberlanjutan untuk menaikkan citra perusahaan, membawa manfaat bagi organisasi dan memastikan keberlanjutan perusahaan. Sustainability report adalah bagian penting dari operasi perusahaan dan memberikan kontribusi sukarela terhadap lingkungan, etika, dan masyarakat (Kanji \& Chopra, 2010).

Di Indonesia, sustainability report telah menjadi kewajiban bagi perseroan terbatas yang dalam operasinya memanfaatkan sumber daya alam. Hal ini diatur dalam UndangUndang Tahun 2007 Nomor 40 dan Nomor 25 tentang Perseroan Terbatas dan Penanaman Modal mengatur kewajiban perusahaan untuk melaksanakan rencana tanggung jawab sosial perusahaan (Pemerintah Indonesia, 2007). Lawrance Loh, Direktur CGIO National University of Singapore Business School mengatakan banyak negara/kawasan telah melakukan laporan tingkat tinggi tentang sustainability report, namun hal ini tidak secara otomatis meningkatkan kualitas praktik mereka. Banyak perusahaan di Indonesia, Malaysia, Singapura dan Thailand prihatin tentang pentingnya sustainability report. Pernyataan tersebut menyiratkan bahwa perusahaan penting untuk meningkatkan kualitas pengungkapan sustainability report (Suastha, 2016).

Disisi lain banyak perusahaan Indonesia yang mulai meningkatkan kualitas sustainability report. Hal ini dapat dilihat dari penghargaan yang berhasil diterima, salah satunya adalah perusahaan Sampoerna. Sampoerna merupakan satu dari 200 perusahaan yang berasal dari 16 negara di Asia yang terpilih menerima pengakuan dari Enterprise Asia dalam ajang Asia Responsible Award 2019 yang diselenggarakan pada tahun 2019 di Taipe, Taiwan. Penghargaan ini diberikan oleh Enterprise Asia atas upaya perseroan yang dinilai berhasil mengurangi jejak karbon dalam menjalankan usahanya. Dalam ajang ini Sampoerna menerima penghargaan untuk kategoti Green Leadership Award (Setiawan, 2019).

Penelitian ini menggunakan standalone report, assurance report dan GRI reporting framework sebagai faktor yang dapat mempengaruhi kualitas pengungkapan sustainability report. Kualitas pengungkapan sustainability report itu sendiri adalah mutu atau tingkat baik buruknya perusahaan dalam pengungkapkan informasi mengenai sustainability report kepada pihak luar. Dipilihnya variabel standalone report, assurance report dan GRI reporting framework karena banyak hasil penelitian yang masih inkonsistensi seperti Michelon et al. (2015) yang menunjukkan bahwa standalone report, assurance report dan GRI reporting framework tidak berpengaruh terhadap kualitas pengungkapan sustainability report sedangkan Nasution \& Adhariani (2016) menunjukan sebaliknya yaitu standalone report, assurance report dan GRI Reporting Framework berpengaruh secara signifikan terhadap kualitas pengungkapan sustainability report.

Penelitian ini berbeda dengan penelitian terdahulu seperti penelitian dari Michelon et

Trihatmoko / Keberlanjutan : Jurnal Manajemen dan Jurnal Akuntansi, 5 (2) 2020, 142-156.
ISSN : 2614-3291 (online) http://dx.doi.org/10.32493/keberlanjutan.v5i2.y2020.p142-156 
al. (2015) dan Nasution \& Adhariani (2016). Perbedaan penelitian ini dengan penelitian Michelon et al. (2015) dan Nasution \& Adhariani (2016) adalah sampel yang digunakan dalam penelitian ini adalah perusahaan yang terdaftar di Bursa Efek Indonesia tahun 20162018 yang tidak digunakan dipenelitian sebelumnya. Pemilihan tahun penelitian mulai tahun 2016-2018 karena keluarnya Peraturan Menteri ESDM No 41 Tahun 2016 yang mengatur pengembangan dan pemberdayaan masyarakat dalam kegiatan usaha pertambangan mineral dan batubara yang menjadi acuan utama bagi perusahaan pertambangan dalam membuat rencana dan pelaksanaan program sustainability report. Pengukuran variabel dependen juga berbeda dari penelitian sebelumnya dimana dalam penelitian ini merujuk pada Haniffa \& Cooke (2005) dalam mengukur kualitas pengungkapan sustainability report.

Laporan sustainability report yang berdiri sendiri (standalone report) dianggap sebagai sarana yang bagus bagi perusahaan dan pemangku kepentingan untuk mengomunikasikan masalah yang terkait dengan masalah sosial dan lingkungan (Dingwerth \& Eichinger, 2010). Ini karena sustainability report yang standalone report berfokus pada pembahasan masalah sosial, ekonomi dan lingkungan dalam sebuah laporan. Cho et al. (2012) serta Patten \& Zhao (2014) menunjukkan bahwa perusahaan dapat meningkatkan tanggung jawab dan reputasinya terhadap masalah tersebut dengan menggunakan sustainability report yang standalone report karena informasi terkait masalah social, ekonomi dan lingkungan akan lebih terintegrasi, transparan, lengkap, dan akuntabel. Hasil penelitian Nasution \& Adhariani (2016) dan Mahoney et al. (2013) menyatakan bahwa variabel standalone report memiliki pengaruh pada kualitas pengungkapan sustainability report, hasil penelitian lain yang dikemukakan oleh Anugerah et al. (2018) dan Michelon et al. (2015) menyatakan bahwa tidak adanya pengaruh antara standalone report pada kualitas pengungkapan sustainability report.

Dalam beberapa tahun terakhir, perusahaan juga sudah banyak yang menggunakan assurance report untuk meningkatkan kredibilitas, kepercayaan, dan menjamin kualitas informasi sustainability report yang diungkapkan. Utama (2011) menunjukkan bahwa layanan jaminan atau sertifikasi terkait sustainability report oleh pihak independen diperlukan demi memastikan bahwa informasi lingkungan yang dilaporkan oleh perusahaan dapat secara wajar mencerminkan aktivitas lingkungan dan dampak sosial dari aktivitas perusahaan. Hasil penelitian Nasution \& Adhariani (2016) dan Maroun (2019) menyatakan bahwa assurance report memiliki pengaruh pada kualitas pengungkapan sustainability report. Hasil penelitian lain yang dikemukakan oleh Anugerah et al. (2018) dan Michelon et al. (2015) menyatakan bahwa tidak adanya pengaruh antara assurance services pada kualitas pengungkapan sustainability report.

GRI reporting framework memulai pelaporan tentang aktivitas organisasi berupa sosial, ekonomi maupun lingkungan yang mengacu pada triple bottom line atau sering disebut dengan 3P (profit, people, planet). Panduan sustainability report GRI reporting framework membantu sebuah perusahaan melaporkan kinerja ekonomi, lingkungan, dan sosial mereka, dan meningkatkan akuntabilitas pelaporan. Panduan ini berisi prinsip-prinsip yang mendefinisikan konten sustainability report dan memastikan informasi yang diungkapkan memiliki nilai yang tinggi (GRI, 2011).

\section{LANDASAN TEORITIS DAN PENGEMBANGAN HIPOTESIS Stakeholder Theory}

Memasuki era digital, sebuah perusahaan diminta untuk lebih memperhatikan para stakeholders. Hal ini juga diharapkan memberikan manfaat ekonomiVsehingga perseroan akan terus menjadi perseroan yang terus beroperasi. Teori stakeholder pertama kali dikenalkan pada tahun 1963 oleh Stanford Institute (RSI). Lindawati \& Puspita (2015) membagi perubahan perusahaan lingkungan menjadi kategori internal dan eksternal.

Trihatmoko / Keberlanjutan: Jurnal Manajemen dan Jurnal Akuntansi, 5 (2) 2020, 142-156.
ISSN : 2614-3291 (online) http://dx.doi.org/10.32493/keberlanjutan.v5i2.y2020.p142-156 
Pemilik perusahaan, konsumen, karyawan, dan pemasok adalah yang masuk lingkungan internal. Lingkungan eksternal itu sendiri termasuk pesaing, pemerintah, pendukung konsumen, dan pemerhati lingkungan.

Teori ini sejalan dengan variabel yang digunakan yaitu tekanan stakeholders, standalone report, assurance report dan GRI reporting framework. Tekanan yang diberikan oleh primary stakeholder lebih besar daripada secondary stakeholder sehingga perusahaan berusaha menjalankan tanggung jawab sesuai dengan keinginan primary stakeholder. Hal ini juga berpengaruh pada kualitas pengungkapan sustainability report perusahaan. Tekanan primary stakeholder dan ekspektasi tanggung jawab sosial mempengaruhi pengungkapan kualitas sustainability report perusahaan. Standalone report dapat membantu perusahaan untuk memastikan bahwa pihak manajemen berperilaku sesuai dengan keinginan stakeholder, yang merupakan dasar dari tanggung jawab perusahaan menurut stakeholder theory. Sustainability report yang menggunakan jasa assurance terlihat lebih dapat diandalkan dan berkualitas untuk pengambilan keputusan perusahaan dan stakeholder dibanding yang tidak diassurance. Perusahaan mencari assurance untuk dapat meningkatkan komunikasi dengan stakeholder. Perusahaan yang menggunakan GRI reporting framework sebagai panduannya dianggap lebih transparan mengenai informasi yang dibutuhkan dan meningkatkan kualitas yang dianggap oleh stakeholder sebagai cara yang baik dalam pengungkapan informasi perusahaan.

\section{Legitimacy Theory}

Teori legitimasi didasarkan pada adanya kontrak sosial antara perusahaan dan lingkungan sosial tempat mereka beroperasi. Kontrak tersebut menetapkan bahwa selama keberadaan dan aktivitas perusahaan diterima secara sah oleh masyarakat, maka perusahaan dapat terus beroperasi (Rossi \& Tarquinio, 2017). Legitimasi ada ketika tindakan perusahaan dianggap sesuai dalam sistem norma, nilai, keyakinan, dan definisi dari struktur sosial tertentu. Legitimasi perusahaan diperlukan untuk kelangsungan hidup perusahaan. Oleh karena itu, perusahaan melakukan kegiatan yang berbeda dengan tujuan meningkatkan legitimasi.

Teori legitimasi menganjurkan perusahaan untuk meyakinkan bahwa aktivitas dan kinerjanya dapat diterima oleh masyarakat. Perusahaan menggunakan sustainability report mereka untuk menggambarkan kesan tanggung jawab lingkungan, sehingga mereka diterima oleh masyarakat. Dengan adanya penerimaan dari masyarakat tersebut diharapkan dapat meningkatkan nilai perusahaan sehingga dapat meningkatkan laba perusahaan. Perusahaan dapat menggunakan assurance report untuk meningkatkan kepercayaan masyarakat dalam akurasi dan reliability sustainability report perusahaan dan untuk mempertahankan legitimasi perusahaan (Perego \& Kolk, 2012). Assurance report merupakan alat strategis yang dapat digunakan perusahaan untuk melegitimasi kegiatan mereka dan untuk mempengaruhi persepsi masyarakat tentang legitimasi perilaku perusahaan (O'Dwyer et al., 2011). Perusahaan memutuskan untuk memastikan sustainability report berfungsi untuk melegitimasi kegiatan mereka yang terkait dengan lingkungan dan meningkatkan kredibilitas laporan. Dengan cara ini, mereka mengirim sinyal positif yang diarahkan untuk meningkatkan legitimasi sosial perusahaan. Sebaliknya, jenis legitimasi yang dicari oleh pemangku kepentingan perusahaan adalah legitimasi moral dan kognitif.

\section{Pengembangan Hipotesis \\ Pengaruh Standalone Report terhadap Kualitas Pengungkapan Sustainability Report}

Menurut Dilling (2010), Standalone adalah kumpulan tersendiri antara informasi mengenai lingkungan dengan sosial. Terlepas dari nama, terminologi atau judulnya, suatu laporan dapat dikatakan standalone ketika laporan memenuhi kriteria yang ada, yaitu

Trihatmoko / Keberlanjutan: Jurnal Manajemen dan Jurnal Akuntansi, 5 (2) 2020, 142-156.
ISSN : 2614-3291 (online) http://dx.doi.org/10.32493/keberlanjutan.v5i2.y2020.p142-156 
pertama fokus pada isu lingkungan dan masalah sosial dan yang kedua berbeda dengan laporan tahunan.

Cho et al. (2012) menunjukkan bahwa perusahaan dapat membuktikan rasa tanggung jawabnya dengan cara menggunakan sustainability report yang standalone. Mahoney et al. (2013) menunjukkan bahwa sebuah entitas yang menggunakan sustainability report sebagai sinyal memiliki tingkat komitmen yang tinggi terhadap sustainability report. Dhaliwal et al. (2014) menggunakan sustainability report yang standalone sebagai alat untuk mengukur kualitas pengungkapan sustainability report dalam penelitiannya. Sebab, berdasarkan penelitian sebelumnya, laporan sustainability report yang standalone diyakini dapat memperdalam kualitas sustainability report. Mahoney et al. (2013) dan Gao \& Bansal (2013) menunjukkan bahwa menerbitkan sustainability report yang standalone dapat meningkatkan serta memperdalam kinerja pengungkapan sustainability report secara umum. Helfaya \& Moussa (2017) dan Hong \& Andersen (2011) juga mengatakan hal yang sama bahwa perusahaan yang menggunakan sustainability report yang terpisah dianggap lebih memiliki kualitas pengungkapan yang lebih baik.

Teori stakeholder menyatakan bahwa semakin kuat hubungan perusahaan dengan pemangku kepentingan, maka akan semakin baik bisnis perusahaan. Sebaliknya, semakin buruk hubungan perusahaan dengan pemangku kepentingan, maka akan semakin sulit. Hubungan yang kuat dengan para pemangku kepentingan adalah berdasarkan kepercayaan, rasa hormat, dan kerjasama. Tekanan yang diberikan oleh primary stakeholder lebih besar daripada secondary stakeholder sehingga perusahaan berusaha menjalankan tanggung jawab sesuai dengan keinginan primary stakeholder. Hal ini juga berpengaruh pada kualitas pengungkapan sustainability report perusahaan. Tekanan primary stakeholder dan ekspektasi tanggung jawab sosial mempengaruhi pengungkapan kualitas sustainability report perusahaan. Standalone report dapat membantu perusahaan untuk memastikan bahwa pihak manajemen berperilaku sesuai dengan keinginan stakeholder, yang merupakan dasar dari tanggung jawab perusahaan.

$\mathrm{H}_{1}$ : Standalone report berpengaruh positif terhadap kualitas pengungkapan sustainability report.

\section{Pengaruh Assurance Report terhadap Kualitas Pengungkapan Sustainability Report}

Assurance yang dalam prosesnya berfokus kepada apa yang dibutuhkan pihak yang berkepentingan dan dilaksanakan sesuai aturan dan standar serta prinsip assurance, maka assurance atas sustainability report dapat menaikkan kelengkapan informasi dan kredibilitas atas sustainability report tersebut (Adams \& Evans, 2014). Hal tersebut dikarenakan assurance yang selama ini sering dipakai oleh perusahaan memang bertujuan untuk menarik pihak luar yang dimana pihak manajemen membutuhkan dukungan terlebih masalah keuangan untuk ikut serta dalam pembangunan sebuah perusahaan. Maroun (2019) menyatakan sebagai sebuah penyedia jasa assurance, auditor dapat bertindak mewakili suara bagi pemangku kepentingan yang pada akhirnya dapat mempengaruhi sikap manajer terhadap pemangku kepentingan. Hal ini dapat mendorong meningkatnya partisipasi dalam proses pelaporan sustainability report terkait masalah sosial dan lingkungan yang menguntungkan para pemangku kepentingan. Penelitian Nasution \& Adhariani (2016), Wong \& Millington (2014), Casey \& Grenier (2014), Cohen \& Simnett (2015) dan Patten \& Zhao (2014) mendukung hal tersebut yang menunjukkan bahwa assurance report dapat dikatakan sebagai praktik pelaporan sustainability report yang substantif yang dilaksanakan oleh pihak manajemen dan digunakan untuk meningkatkan kualitas atas pengungkapan sustainability report.

Kebijakan perusahaan untuk melakukan assurance bukan tanpa alasan. Perusahaan dalam melakukan assurance berdasarkan pertimbangan 2 hal yaitu biaya dan manfaatnya. Manfaat yang dimaksud adalah meningkatnya kualitas informasi yang disajikan dalam

Trihatmoko / Keberlanjutan: Jurnal Manajemen dan Jurnal Akuntansi, 5 (2) 2020, 142-156.
ISSN : 2614-3291 (online) http://dx.doi.org/10.32493/keberlanjutan.v5i2.y2020.p142-156 
laporan serta meningkatnya reputasi perusahaan. Hal ini dapat dihubungkan dengan teori legitimacy, dimana perusahaan akan mendapat image yang baik dari masyarakat sebagai benefit dari tanggung jawab perusahaan. Image dan reputasi yang baik menjadi pertimbangan investor untuk berinvestasi yang pada akhirnya dapat meningkatkan nilai laporan perusahaan.

$\mathrm{H}_{2}$ : Assurance report berpengaruh positif terhadap kualitas pengungkapan sustainability report.

\section{Pengaruh GRI Reporting Framework terhadap Kualitas Pengungkapan Sustainability Report}

GRI reporting framework adalah pelopor dalam hal kerangka yang digunakan dalam pelaporan sustainability report (Michelon et al., 2015). Sebagian besar perusahaan di dunia yang menerbitkan laporan sustainability report telah mengadopsi kerangka pelaporan ini. GRI reporting framework bertujuan untuk meningkatkan kualitas informasi sustainability report perusahaan guna meningkatkan interaksi dengan pihak pemangku yang berkepentingan. Kerangka pelaporan yang ada ssat ini memang dirancang dapat memandu perusahaan untuk memberikan informasi tentang perusahaan dan indikator kinerja keuangan, lingkungan dan sosial. Dengan mengacu pada GRI reporting framework diharapkan transparansi perusahaan dengan pihak pemangku yang berkepentingan dan kualitas informasi yang dihasilkannya jauh lebih baik (GRI, 2011).

Habek (2017) menemukan perusahaan yang dalam menyusun sustainability report mengikuti GRI reporting framework kinerja pengungkapan sustainability report-nya mengalami peningkatan. Perusahaan yang mengikuti GRI reporting framework umumnya lebih berkomitmen pada sustainability report daripada perusahaan yang tidak mengikuti. Hal yang sama juga dikemukakan oleh Nasution (2016) yang menyatakan bahwa perusahaan yang mengikuti GRI reporting framework setidaknya perusahaan dapat menjaga transparansi yang lebih besar dengan pemangku kepentingan dan informasi yang mereka ungkapkan menjadi lebih tinggi. Hal ini juga didukung oleh hasil penelitian dari Kuzey \& Uyar (2017) yang menunjukkan bahwa GRI reporting framework berpengaruh terdapat kualitas pengungkapan sustainability report.

Hal ini sejalan dengan teori stakeholder yang menggambarkan kepada siapa saja perusahaan bertanggung jawab. GRI reporting framework sebagai panduan dalam melaporkan informasi keberlanjutan dianggap lebih transparan mengenai informasi yang dibutuhkan dan meningkatkan kualitas yang dianggap oleh stakeholder sebagai cara yang baik dalam pengungkapan informasi perusahaan. Perusahaan yang mengadopsi GRI dianggap menggunakan pendekatan substantif dalam melakukan praktik pelaporan keberlanjutan, yaitu perusahaan mentransformasikan kebijakan dan strategi bisnisnya untuk selaras dengan tujuan keberlanjutan dan norma sosial yang ada.

$\mathrm{H}_{3}$ : $\mathrm{GRI}$ reporting framework berpengaruh positif terhadap kualitas pengungkapan sustainability report.

\section{METODE PENELITIAN \\ Definisi Operasional dan Pengukuran Variabel}

Variabel independen dalam dalam penelitian ini ada 3 (tiga), yaitu standalone report $\left(\mathrm{X}_{1}\right)$, assurance report $\left(\mathrm{X}_{2}\right)$ dan $\mathrm{GRI}$ reporting framework $\left(\mathrm{X}_{3}\right)$. Kualitas pengungkapan sustainability report $(\mathrm{Y})$ adalah variabel dependen dalam penelitian ini. Variabel kontrol yang digunakan ada 2 (dua) yaitu ukuran perusahaan dan umur perusahaan.

\section{Standalone report}

Standalone report adalah informasi lingkungan dan sosial yang disajikan secara terpisah. Contoh nama atau istilah laporan mengenai informasi lingkungan dan sosial adalah laporan keberlanjutan (sustainability reports). Standalone report harus memenuhi dua

Trihatmoko / Keberlanjutan : Jurnal Manajemen dan Jurnal Akuntansi, 5 (2) 2020, 142-156.
ISSN : 2614-3291 (online) http://dx.doi.org/10.32493/keberlanjutan.v5i2.y2020.p142-156 
kriteria, laporan dapat memenuhi kriteria yang ada, yaitu pertama fokus pada isu lingkungan dan masalah sosial dan yang kedua berbeda dengan laporan tahunan. Pengukuran standalone report menggunakan dummy yaitu bernilai 1 apabila perusahaan merilis sustainability report yang berdiri sendiri, dan bernilai 0 apabila informasi sustainability report didalam laporan tahunan dilaporkan tersendiri.

\section{Assurance report}

Assurance report adalah laporan atau pernyataan dari pihak professional yang independen mengenai akurasi dan reliability data untuk laporan yang dijaminnya. Tujuan dari assurance report adalah untuk meningkatkan keyakinan mutu informasi bagi pihak eksternal. Pengukuran assurance report menggunakan dummy yaitu bernilai 1 apabila sustainability report mempunyai pernyataan assurance report, dan bernilai 0 apabila tidak.

\section{GRI reporting framework}

GRI reporting framework adalah pedoman yang memberikan prinsip-prinsip pelaporan, pengungkapan standar dan pedoman implementasi bagi organisasi untuk menyiapkan sustainability report. Pedoman ini juga memberikan referensi internasional untuk semua pihak yang terlibat dalam pengungkapan dengan metode tata kelola dan kinerja lingkungan, sosial dan ekonomi organisasi dan dampaknya. Peraturan Otoritas Jasa Keuangan (POJK) juga digunakan perusahaan sebagai standar pelaporan pengungkapan sustainability report. Pengukuran GRI reporting framework menggunakan dummy yaitu bernilai 1 apabila sustainability report berisikan pernyataan pengadopsian GRI dan standar yang lain, dan bernilai 0 apabila tidak.

\section{Kualitas pengungkapan sustainability report}

Kualitas pengungkapan sustainability report adalah mutu atau tingkat baik buruknya perusahaan dalam mengungkapkan informasi mengenai kinerja lingkungan, sosial dan tata kelola kepada pihak luar. Pengukuran indeks kualitas pengungkapan sustainability report merujuk pada Haniffa \& Cooke (2005) dalam mengidentifikasi item atau konten analisis menggunakan total skor kualitas pengungkapan sustainability report masing-masing perusahaan untuk dibandingkan dengan total skor pengungkapan maksimum.

\section{Populasi dan Sampel}

Populasi yang digunakan pada penelitian ini adalah perusahaan terdaftar di Bursa Efek Indonesia (BEl) yang menerbitkan sustainability report selama periode 2016-2018. Pengambilan sampel adalah prosedur pemilihan jumlah bagian dari populasi yang akhirnya penelitian sampel dapat meringkas karakteristik bagian populasi tersebut. Penelitian ini memakai prosedur purposive sampling. Purposive sampling adalah prosesur pengambilan sampel yang menetapkan jumlah sampel pada kisaran standar yang akan digunakan peneliti untuk memperlihatkan hasil yang baik. Peneliti menggunakan beberapa kriteria, terdiri dari:

1. Perusahan yang terdaftar di Bursa Efek Indonesia (BEI) yang menerbitkan sustainability report selama tahun 2016-2018.

2. Perusahaan yang memiliki data lengkap yang diperlukan dalam penelitian.

Tabel 1. Pemilihan Sampel Penelitian

\begin{tabular}{cll}
\hline No. & \multicolumn{1}{c}{ Rincian Kriteria Sampel } & Keterangan \\
\hline 1 & Jumlah perusahaan yang terdaftar di Bursa Efek Indonesia yang & 64 \\
2 & menerbitkan sustainability report selama tahun 2016-2018 & 64 \\
3 & Perusahaan yang tidak memiliki data lengkap & $(15)$ \\
4 & Jumlah perusahaan yang menenuhi kriteria & 49 \\
5 & Data outlier & 147 \\
6 & Total sampel penelitian & $(2)$ \\
\hline
\end{tabular}
Sumber: Data Penelitian, 2020

Trihatmoko / Keberlanjutan: Jurnal Manajemen dan Jurnal Akuntansi, 5 (2) 2020, 142-156.
ISSN : 2614-3291 (online) http://dx.doi.org/10.32493/keberlanjutan.v5i2.y2020.p142-156 


\section{Teknik Analisis Data}

Teknik analisis data yang digunakan dalam penelitian ini adalah teknik analisis regresi linier berganda dengan menggunakan program Statistical Package Social Sciene (SPSS). Regresi linier berganda dipilih karena untuk melihat ada tidaknya pengaruh variabel bebas terhadap variabel terikat. Proksi yang digunakan dalam model disesuaikan dengan karakteristik populasi perusahaan Indonesia. Model regresi linier berganda dapat menggunakan persamaan:

$$
\text { QUALITY }=\alpha+\beta_{1} \text { SAR }+\beta_{2} \mathrm{AR}+\beta_{3} \mathrm{GRI}+\beta_{4} \mathrm{FSIZE}+\beta_{5} \mathrm{FAGE}+\varepsilon
$$

Keterangan:

$\begin{array}{ll}\text { QUALITY } & =\text { Kualitas pengungkapan sustainability report } \\ \alpha & =\text { Koefisien konstanta } \\ \beta_{1,2,3} & =\text { Koefisien variabel independen } \\ \text { SAR } & =\text { Perilisan sustainability report } \\ \text { AR } & =\text { Pernyataan assurance report } \\ \text { GRI } & =\text { Pernyataan pengadopsian GRI reporting framework } \\ \text { FSIZE } & =\text { Ukuran Perusahaan } \\ \text { FAGE } & =\text { Umur Perusahaan } \\ \varepsilon & =\text { Error }\end{array}$

\section{HASIL PENELITIAN DAN PEMBAHASAN Analisis Statistik Deskriptif}

Analisis statistik deskriptif merupakan metode yang digunakan untuk menganalisis data kuantitatif untuk memperoleh gambaran tentang data penelitian. Kualitas pengungkapan sustainability report adalah variabel variabel dependen yang digunakan dalam penelitian ini, serta standalone report, assurance report dan GRI reporting framework sebagai variabel independen. Berikut akan dilakukan statistik deskriptif atas masing-masing variabel dengan melihat nilai minimum, maksimum, rerata (mean) dan standar deviasi dari tabel hasil pengujian data.

Tabel 2. Statistik Deskriptif

\begin{tabular}{|c|c|c|c|c|c|}
\hline Variabel & Observasi & Minimum & Maksimum & Rata-rata & Std. Deviasi \\
\hline QUALITY & 145 & 0,0649351 & 0,6703297 & 0,2425919 & 0,1237296 \\
\hline FSIZE & 145 & 28,175360 & 34,798751 & 31,350030 & 1,564428 \\
\hline FAGE & 145 & 1 & 41 & 18,94 & 9,422 \\
\hline \multicolumn{6}{|l|}{ Dummy } \\
\hline Variabel & Observasi & \multicolumn{2}{|c|}{$\begin{array}{l}\text { Jumlah Variabel yang } \\
\text { Bernilai } 1\end{array}$} & Persentase & \\
\hline $\begin{array}{l}\text { SAR } \\
\text { AR } \\
\text { GRI }\end{array}$ & $\begin{array}{l}145 \\
145 \\
145 \\
\end{array}$ & $\begin{array}{l}123 \\
42 \\
129\end{array}$ & & $\begin{array}{l}84,8 \% \\
29,0 \% \\
89,0 \% \\
\end{array}$ & \\
\hline
\end{tabular}

Sumber: Output SPSS, 2020

Berdasarkan tabel 2 variabel kualitas pengungkapan sustainability report memiliki rata-rata sebesar 0,2425919 yang tergolong rendah. Nilai standar deviasi sebesar 0,1237296 , apabila nilai rerata dibandingkan dengan nilai standar deviasi memperlihatkan bahwa nilai standar deviasi memiliki nilai yang lebih kecil atau lebih rendah dari nilai rerata yang berarti tingkat sebaran data kualitas pengungkapan sustainability report terbilang kecil atau homogen, sehingga hal ini mengisyaratkan data kualitas pengungkapan sustainability

Trihatmoko / Keberlanjutan : Jurnal Manajemen dan Jurnal Akuntansi, 5 (2) 2020, 142-156.
ISSN : 2614-3291 (online) http://dx.doi.org/10.32493/keberlanjutan.v5i2.y2020.p142-156 
report tidak begitu bervariasi. Variabel standalone report memperoleh skor 1 atau perusahaan yang memiliki standalone report sebanyak 123 sampel atau 84,8\%, hal ini menunjukkan bahwa mayoritas atau lebih dari $50 \%$ perusahaan telah menggunakan laporan yang terpisah. Variabel assurance report memperoleh skor 1 atau perusahaan yang memiliki assurance report sebanyak 42 sampel atau $29,0 \%$, hal ini menunjukkan bahwa masih sedikit perusahaan yang belum menggunakan jasa independen dalam laporan keberlanjutaanya. Variabel GRI reporting framework memperoleh skor 1 atau perusahaan yang mengadopsi GRI reporting framework sebanyak 129 sampel atau 89,0\%, hal ini menunjukkan bahwa hampir semua perusahaan menggunakan GRI dalam menyusun laporan keberlanjutannya.

\section{Uji Normalitas}

\begin{tabular}{ll}
\multicolumn{2}{c}{ Tabel 3. Hasil Uji Normalitas } \\
\hline $\mathrm{N}$ & Unstandardizes Residual \\
Test Statistic & 145 \\
Asymp. Sig. (2-tailed) & 0,072 \\
\hline
\end{tabular}

Sumber: Output SPSS, 2020

Uji normalitas pada penelitian ini menggunakan uji statistik non-parametrik Kolmogorov-Smirnov karena mengukur kesesuaian distribusi data observasi dengan frekuensi tertentu dalam satu sampel. Berdasarkan tabel 3 dapat dilihat bahwa nilai Asymp. Sig. (2-tailed) sebesar 0,063 $(0,063>0,05)$, dengan demikian dapat dilihat bahwa data residual model regresi berdistribusi normal.

\section{Uji Multikolinearitas}

Tabel 4. Hasil Uji Multikolinearitas

\begin{tabular}{|c|c|c|c|}
\hline \multirow{2}{*}{ Mode } & & \multicolumn{2}{|c|}{ Collinearity Statistic } \\
\hline & & Tolerance & VIF \\
\hline \multirow[t]{6}{*}{1} & (Constant) & & \\
\hline & SAR & 0,299 & 3,345 \\
\hline & AR & 0,896 & 1,116 \\
\hline & GRI & 0,285 & 3,515 \\
\hline & FSIZE & 0,824 & 1,214 \\
\hline & FAGE & 0,977 & 1,023 \\
\hline
\end{tabular}

Sumber: Output SPSS, 2020

Berdasarkan tabel 4 dapat dilihat bahwa nilai tolerance semua variabel lebih besar dari 0,10 dan nilai VIF kurang dari 10 yang berarti bahwa model regresi layak digunakan karena keempat variabel independen tersebut tidak terjadi multikolinieritas.

\section{Uji Heterokedastisitas}

Tabel 5. Hasil Uji Heterokedastisitas

\begin{tabular}{cll}
\hline Model & & Sig. \\
\hline 1 & (Constant) & 0,485 \\
& SAR & 0,145 \\
& AR & 0,794 \\
& GRI & 0,219 \\
& FSIZE & 0,675 \\
& FAGE & 0,128 \\
\hline
\end{tabular}

Sumber: Output SPSS, 2020

Trihatmoko / Keberlanjutan : Jurnal Manajemen dan Jurnal Akuntansi, 5 (2) 2020, 142-156.
ISSN : 2614-3291 (online) http://dx.doi.org/10.32493/keberlanjutan.v5i2.y2020.p142-156 
Berdasarkan tabel 5 dapat dilihat bahwa semua variabel memiliki nilai signifikansi lebih dari 0,05. Hal ini menandakan model regresi layak digunakan karena model regresi tidak terjadi heteroskedastisitas.

\section{Goodness of Fit}

Tabel 6. Hasil Goodness of Fit

\begin{tabular}{cc}
\hline Model & Adjusted R Square \\
\hline 1 & 0,137 \\
\hline
\end{tabular}

Sumber: Output SPSS, 2020

Berdasarkan tabel 6 didapat nilai adjusted $R$ square sebesar 0,137 . Hal ini menunjukkan bahwa 13,7 persen variabel independen yang terdiri dari standalone report, assurance report dan GRI reporting framework serta variabel kontrol yang terdiri dari ukuran perusahaan dan umur perusahaan dapat menjelaskan variabel kualitas pengungkapan sustainability report, sedangkan 86,3 persen sisanya dijelaskan dengan variabel selain variabel independen standalone report, assurance report dan GRI reporting framework serta variabel kontrol ukuran perusahaan dan umur perusahaan.

\section{Regresi Linier Berganda}

\begin{tabular}{clll}
\multicolumn{3}{c}{ Tabel 7. Analisis Regresi Linier Berganda } \\
\hline Model & & B & Sig. \\
\hline 1 & (Constant) & 0,462 & 0,025 \\
& SAR & 0,010 & 0,833 \\
& AR & $-0,026$ & 0,243 \\
GRI & 0,159 & 0,006 \\
& FSIZE & $-0,011$ & 0,106 \\
& FAGE & $-0,001$ & 0,358 \\
\hline
\end{tabular}

Sumber: Output SPSS, 2020

Berdasarkan tabel 7 diatas menunjukkan bahwa variabel standalone report memiliki nilai signifikansi sebesar 0,833. Nilai signifikansi sebesar 0,833 lebih besar dari 0,05 yang menunjukkan bahwa standalone report tidak berpengaruh terhadap kualitas pengungkapan sustainability report, sehingga $\mathrm{H}_{1}$ ditolak. Variabel assurance report memiliki nilai signifikansi sebesar 0,243. Nilai signifikansi sebesar 0,243 lebih besar dari 0,05 yang menunjukkan bahwa assurance report tidak berpengaruh terhadap kualitas pengungkapan sustainability report, sehingga $\mathrm{H}_{2}$ ditolak. Variabel $\mathrm{GRI}$ reporting framework memiliki nilai signifikansi sebesar 0,006. Nilai signifikansi sebesar 0,006 lebih kecil dari 0,05 yang menunjukkan bahwa GRI reporting framework berpengaruh terhadap kualitas pengungkapan sustainability report, sehingga $\mathrm{H}_{3}$ diterima. Berdasarkan hasil diatas dapat ditarik persamaan regresi linier berganda sebagai berikut:

\section{QUALITY $=0,462+0,10$ SAR $-0,026$ AR $+0,159 \mathrm{GRI}-0,011 \mathrm{FSIZE}-0,001 \mathrm{FAGE}+\varepsilon$}

Dari persamaan diatas dapat dijelaskan bahwa konstanta a sebesar 0,462 yang artinya jika variabel independen dianggap konstan, maka kualitas pengungkapan sustainability report akan bertambah sebesar 0,462. Koefisien regresi standalone report sebesar 0,10 memperlihatkan bahwa setiap penambahan standalone report jika variabel lainnya dianggap konstan, maka standalone report akan bertambah sebesar 0,10. Koefisien regresi assurance report sebesar -0,026 memperlihatkan bahwa setiap penambahan assurance report jika variabel lainnya dianggap konstan, maka assurance report akan berkurang sebesar 0,026. Koefisien regresi GRI reporting framework sebesar 0,159 memperlihatkan bahwa setiap penambahan GRI reporting framework jika variabel lainnya dianggap konstan, maka GRI reporting framework akan bertambah sebesar 0,159. Koefisien

Trihatmoko / Keberlanjutan : Jurnal Manajemen dan Jurnal Akuntansi, 5 (2) 2020, 142-156.
ISSN : 2614-3291 (online) http://dx.doi.org/10.32493/keberlanjutan.v5i2.y2020.p142-156 
regresi ukuran perusahaan (firm size) sebesar -0.011 memperlihatkan bahwa setiap penambahan ukuran perusahaan (firm size) jika variabel lainnya dianggap konstan, maka firm size akan berkurang sebesar 0.011 . Koefisien regresi ukuran perusahaan (firm age) sebesar -0,001 memperlihatkan bahwa setiap penambahan (firm age) jika variabel lainnya dianggap konstan, maka ukuran perusahaan (firm age) akan berkurang sebesar 0,001.

\section{Standalone Report terhadap Kualitas Pengungkapan Sustainability Report}

Hasil dari analisis regresi menunjukkan bahwa standalone report tidak berpengaruh terhadap kualitas pengungkapan sustainability report yang artinya $\mathrm{H}_{1}$ ditolak. Hal ini mengisyaratkan bahwa pelaksanaan pelaporan sustainability report tersebut kemungkinan besar dilakukan pihak manajemen dengan menggunakan metode simbolik. Pengungkapan informasi sukarela hanyalah alat untuk memberikan kesan positif dan mengelola hubungan dengan pihak eksternal perusahaan terlepas dari peningkatan informasi yang diungkapkan. Hal ini dapat digambarkan dengan legitimacy theory bahwa salah satu upaya yang dapat dilakukan perusahaan adalah menyalahgunakan laporan keberlanjutan untuk memenuhi legitimasi perusahaan. Manajemen dapat menyampaikan sustainability report melalui standalone report demi meningkatkan citra dimata pihak yang berkepentingan tanpa mengubah strategi atau langkah-langkah prosedur yang nantinya berdampak signifikan terhadap kinerja utamnya sosial, ekonomi serta lingkungan perusahaan.

Interpretasi berdasarkan Michelon et al. (2015) adalah perusahaan menerbitkan sustainability report yang berdiri sendiri untuk tujuan greenwashing. Greenwashing merupakan strategi legitimasi yang diterapkan oleh perusahaan melalui sustainability report secara sukarela untuk menciptakan citra perusahaan yang menjunjung tinggi nilai-nilai sosial, ekonomi serta lingkungan. Faktanya, belum terbukti jika perusahaan memang benar beroperasi sesuai dengan nilai-nilai sosial, ekonomi serta lingkungan yang diinginkan masyarakat (Lindblom, 1994). Lindblom (1994) percaya bahwa salah satu cara untuk mendapatkan legitimasi adalah melalui simbolisme seperti memanipulasi pandangan para pemangku kepentingan. Menurut argumen greenwashing, perusahaan menerbitkan sustainability report yang standalone report untuk memvisualisasikan perusahaan sebagai korporat yang baik (good corporate citizen), tetapi tidak demikian (Greer \& Bruno, 1996). Greenwashing menyertakan praktik yang dipilih dengan cermat yang hanya mengungkapkan dampak sosial dan lingkungan yang positif yang akan menyebabkan bias dan menyesatkan pengguna laporan.

Intrepretasi menurut Eccles \& Krzus (2010) adalah kemungkinan banyak perusahaan yang mulai menggunakan pendekatan pelaporan dengan integrated reporting. Annual report dan sustainability report yang dilaporkan secara terpisah membuat pihak yang berkepentingan membayar lebih banyak upaya untuk dapat mendapatkan laporan dan membuat perusahaan membayar lebih banyak. banyak perusahaan yang menggabungkan antara annual report dan sustainability report dalam bentuk pelaporan terintegrasi integrated reporting dengan hanya satu laporan yang mampu memenuhi kebutuhan informasi pemangku kepentingan. Hasil penelitian ini sejalan dengan penelitian yang dilakukan oleh Halma Anugerah et al. (2018) dan Michelon et al. (2015) bahwa standalone report tidak berpengaruh terhadap kualitas pengungkapan sustainability report. Namun hasil penelitian ini bertentangan dengan hasil penelitian yang dilakukan oleh Nasution \& Adhariani (2016) dan Mahoney et al. (2013) yang menyatakan bahwa standalone report berpengaruh terhadap kualitas pengungkapan sustainability report.

\section{Assurance Report terhadap Kualitas Pengungkapan Sustainability Report (SR)}

Hasil dari analisis regresi menunjukkan bahwa assurance report tidak berpengaruh terhadap kualitas pengungkapan sustainability report yang artinya $\mathrm{H}_{2}$ ditolak. Hasil ini menunjukkan bahwa terdapat kecenderungan perusahaan menggunakan pendekatan

Trihatmoko / Keberlanjutan: Jurnal Manajemen dan Jurnal Akuntansi, 5 (2) 2020, 142-156.
ISSN : 2614-3291 (online) http://dx.doi.org/10.32493/keberlanjutan.v5i2.y2020.p142-156 
simbolik dalam laporannya. Singkatnya, assurance report terbatas untuk meningkatkan persepsi pemangku kepentingan daripada meningkatkan kualitas informasi yang diungkapkan. Hal ini merupakan konsekuensi dari legitimacy theory, dimana perusahaan akan mendapat image yang baik dari masyarakat sebagai benefit dari tanggung jawab perusahaan. Image dan reputasi yang baik menjadi pertimbangan investor untuk berinvestasi yang pada akhirnya dapat meningkatkan nilai laporan perusahaan.

Ada berbagai faktor yang dapat menyebabkan assurance report tidak berpengaruh terhadap kualitas pengungkapan sustainability report salah satunya adalah faktor perusahan-perusahaan di Indonesia yang masih jarang menggunakan assurance report. Alasan assurance report yang masih jarang adalah karena perusahaan tidak memiliki kewajiban untuk melakukan assurance report pada sustainability report. Hal ini berkaitan dengan biaya tinggi dan waktu yang lama dalam proses pembuatannya sehingga banyak perusahaan yang pada akhirnya tidak mementingkan adanya assurance report untuk meningkatkan kualitas pengungkapan sustainability report. Selain itu di Indonesia masih sangat terbatas memiliki sejumlah lembaga sertifikasi yang memiliki kemampuan untuk untuk mengarahkan dan memberikan pemahaman bagi perusahaan dalam menyusun sustainability report sehingga banyak perusahaan yang tidak ambil pusing mengenai kualitas pengungkapan sustainability report karena menurut perusahaan masih ada cara lain untuk mendukung nilai perusahaan di mata masyarakat dan pemegang saham.

Hasil penelitian ini sejalan dengan penelitian yang dilakukan oleh Halma Anugerah et al. (2018) dan Michelon et al. (2015) bahwa assurance report tidak berpengaruh terhadap kualitas pengungkapan sustainability report. Namun hasil penelitian ini bertentangan dengan hasil penelitian yang dilakukan oleh Nasution \& Adhariani (2016) dan Maroun (2019) yang menyatakan bahwa assurance report berpengaruh terhadap kualitas pengungkapan sustainability report.

\section{GRI Reporting Framework terhadap Kualitas Pengungkapan Sustainability Report}

Hasil dari analisis regresi menunjukkan bahwa GRI reporting framework berpengaruh positif terhadap kualitas pengungkapan sustainability report yang artinya $\mathrm{H}_{3}$ diterima. Penggunaan kerangka pelaporan GRI memberikan dimensi informasi yang luas dalam hal keberlanjutan perusahaan dan juga wujud perbaikan dan inovasi perusahaan dibidang pengungkapan sustainability report (Voegtlin \& Scherer, 2017). Hal ini menunjukkan bahwa dibandingkan dengan perusahaan yang tidak mengikuti GRI reporting framework, perusahaan yang mengikuti GRI reporting framework untuk menyusun sustainability report memiliki kualitas pengungkapan sustainability report yang lebih tinggi.

Apabila dibandingkan dengan perusahaan yang tidak mengikuti GRI reporting framework, perusahaan yang mengikuti GRI reporting framework umumnya memiliki komitmen pelaporan yang lebih tinggi karena perusahaan dianggap lebih transparan kepada pemangku kepentingan dan informasi yang diungkapkannya lebih berkualitas. Hal ini senada dengan penelitian Mahoney et al. (2013) yang menjelaskan bahwa perusahaan yang mengikuti standar GRI memiliki kinerja ekonomi, sosial dan lingkungan yang lebih tinggi daripada perusahaan yang tidak mengikuti standar GRI. Perusahaan yang mengadopsi GRI dianggap telah menggunakan metode substantif dalam melakukan praktik pelaporan sustainability report, dalam metode ini perusahaan akan mengubah kebijakan dan strategi bisnisnya agar sesuai dengan tujuan pembangunan berkelanjutan dan norma sosial yang ada. Hal ini tercermin dari laporan informasi perusahaan yang berkualitas.

Habek (2017) mengatakan bahwa sustainability report yang disusun sesuai dengan GRI reporting framework memiliki tingkat relevansi, kredibilitas dan kualitas yang lebih tinggi dari informasi yang diungkapkan jika dibandingkan dengan sustainability report yang dikembangkan dengan menggunakan prinsip-prinsip pelaporan individual perusahaan. Hal ini sejalan dengan teori stakeholder yang menggambarkan kepada siapa saja perusahaan

Trihatmoko / Keberlanjutan: Jurnal Manajemen dan Jurnal Akuntansi, 5 (2) 2020, 142-156.
ISSN : 2614-3291 (online) http://dx.doi.org/10.32493/keberlanjutan.v5i2.y2020.p142-156 
bertanggung jawab. GRI reporting framework sebagai panduan dalam melaporkan informasi keberlanjutan dianggap lebih transparan mengenai informasi yang dibutuhkan dan meningkatkan kualitas yang dianggap oleh stakeholder sebagai cara yang baik dalam pengungkapan informasi perusahaan. Hasil penelitian ini sejalan dengan penelitian yang dilakukan oleh Nasution \& Adhariani (2016) dan Habek (2017) bahwa GRI reporting framework berpengaruh positif terhadap kualitas pengungkapan sustainability report. Namun hasil penelitian ini bertentangan dengan hasil penelitian yang dilakukan oleh Anugerah et al. (2018) dan Michelon et al. (2015) yang menunjukkan bahwa GRI reporting framework tidak memiliki pengaruh terhadap kualitas pengungkapan sustainability report.

\section{KESIMPULAN DAN SARAN}

Penelitian ini dilakukan untuk mengetahui pengaruh standalone report, assurance report dan GRI reporting framework terhadap kualitas pengungkapan sustainability report pada perusahaan yang memiliki sustainability report yang terdaftar di Bursa Efek Indonesia periode 2016-2018. Data yang digunakan dalam penelitian ini merupakan data sekunder yang diambil dari berbagai sumber, yaitu dari website resmi BEI dan website perusahaan. Berdasarkan hasil analisis dan pembahasan, dapat diambil kesimpulan sebagai berikut:

1. Standalone report tidak berpengaruh terhadap kualitas pengungkapan sustainability report

2. Assurance report tidak berpengaruh terhadap kualitas pengungkapan sustainability report

3. GRI reporting framework berpengaruh positif terhadap kualitas pengungkapan sustainability report

Penelitian selanjutnya disarankan mempertimbangkan untuk menggunakan variabel lain selain variabel yang digunakan dalam penelitian ini. Hal ini dimungkinkan dapat memberikan hasil perbandingan pengaruh penelitian yang sebelumnya. Organisasi yang menjadi acuan keterbukaan informasi lingkungan diharapkan dapat memberikan penjelasan yang lebih detail tentang indikator pelaporan keberlanjutan, sehingga tidak ada perbedaan asumsi yang dibuat peneliti dalam memahami indikator tersebut.

\section{DAFTAR PUSTAKA}

Adams, C. A., \& Evans, R. (2014). Accountability, Completeness, Credibility and the Audit Expectations Gap. Journal of Corporate Citizenship, 14, 97-115. https://doi.org/10.9774/gleaf.4700.2004.su.00010

Ansell, C., \& Gash, A. (2008). Collaborative governance in theory and practice. Journal of Public Administration Research and Theory, 18(4), 543-571. https://doi.org/10.1093/jopart/mum032

Anugerah, E. G., Saraswati, E., \& Andayani, W. (2018). Quality Of Disclosure And Corporate Social Responsibility Reporting Practices In Indonesia. Jurnal Akuntansi, 12(3), 337353.

Casey, R. J., \& Grenier, J. H. (2014). Understanding and Contributing to the Enigma of Corporate Social Responsibility (CSR) Assurance in the United States. Auditing: A Journal of Practice and Theory, 34(1), 97-130.

Cho, C. H., Michelon, G., \& Patten, D. M. (2012). Enhancement and obfuscation through the use of graphs in sustainability reports: An international comparison. Sustainability Accounting, Management and Policy Journal, 3(1), 74-88. https://doi.org/10.1108/20408021211223561

Cohen, J. R., \& Simnett, R. (2015). CSR and Assurance Services: A Research Agenda. Auditing: A Journal of Practice \& Theory, 34(1), 59-74.

Trihatmoko / Keberlanjutan: Jurnal Manajemen dan Jurnal Akuntansi, 5 (2) 2020, 142-156.
ISSN : 2614-3291 (online) http://dx.doi.org/10.32493/keberlanjutan.v5i2.y2020.p142-156 
Dewi, S. P., \& Keni. (2016). Pengaruh Size, Profitabilitas, Leverage dan Umur Terhadap Pengungkapan Tanggungjawab Sosial Perusahaan. Jurnal Bisnis Dan Akuntansi, 12(1), 59-66.

Dhaliwal, D., Li, O. Z., Tsang, A., \& Yang, Y. G. (2014). Corporate social responsibility disclosure and the cost of equity capital: The roles of stakeholder orientation and financial transparency. Journal of Accounting and Public Policy, 33(4), 328-355. https://doi.org/10.1016/j.jaccpubpol.2014.04.006

Dilling, P. F. A. (2010). Sustainability Reporting In A Global Context: What Are The Characteristics Of Corporations That Provide High Quality Sustainability Reports An Empirical Analysis. International Business \& Economics Research Journal (IBER), 9(1), 19-30. https://doi.org/10.19030/iber.v9i1.505

Dingwerth, K., \& Eichinger, M. (2010). Tamed transparency: How information disclosure under the global reporting initiative fails to empower. Global Environmental Politics, 10(3), 74-96. https://doi.org/10.1162/GLEP_a_00015

Eccles, R. G., \& Krzus, M. P. (2010). One Report - Integrated Reporting For A Sustainable Strategy. In Financial Executive.

Gao, J., \& Bansal, P. (2013). Instrumental and Integrative Logics in Business Sustainability. Journal of Business Ethics, 112(2), 241-255. https://doi.org/10.1007/s10551-012$1245-2$

Greer, J., \& Bruno, K. (1996). Green wash: The Reality Behind Corporate Environmentalism. In New York: Apex Press.

GRI. (2011). GRI Sustainability Reporting: How Valuable is the Journey?. Retrieved April 15, 2019 from https://www.globalreporting.org/resourcelibrary/GRI-Sustainability-Report2008-2009.pdf

Habek, P. (2017). CSR reporting practices in Visegrad Group countries and the quality of disclosure. Sustainability (Switzerland), 9(12), 2322. https://doi.org/10.3390/su9122322

Haniffa, R. M., \& Cooke, T. E. (2005). The impact of culture and governance on corporate social reporting. Journal of Accounting and Public Policy, 24(5), 391-430. https://doi.org/10.1016/j.jaccpubpol.2005.06.001

Helfaya, A., \& Moussa, T. (2017). Do Board's Corporate Social Responsibility Strategy and Orientation Influence Environmental Sustainability Disclosure? UK Evidence. Business Strategy and the Environment, 26(8), 1061-1077. https://doi.org/10.1002/bse.1960

Hong, Y., \& Andersen, M. L. (2011). The Relationship Between Corporate Social Responsibility and Earnings Management: An Exploratory Study. Journal of Business Ethics, 104(4), 461-471. https://doi.org/10.1007/s10551-011-0921-y

Kanji, G. K., \& Chopra, P. K. (2010). Corporate social responsibility in a global economy. Total Quality Management and Business Excellence, 2(12), 119-143. https://doi.org/10.1080/14783360903549808

Kuzey, C., \& Uyar, A. (2017). Determinants of sustainability reporting and its impact on firm value: Evidence from the emerging market of Turkey. Journal of Cleaner Production, 143, 27-39. https://doi.org/10.1016/j.jclepro.2016.12.153

Lindawati, A. S. L., \& Puspita, M. E. (2015). Corporate Social Responsibilty: Implikasi Stakeholder dan Legitimacy Gap dalam Peningkatan Kinerja Perusahaan. Jurnal Akuntansi Multiparadigma, 6(1), 157-174.

Lindblom, C. K. (1994). The implications of organizational legitimacy for corporate social performance and disclosure, Working Paper for the American Accounting Association Public Interest Section, USA. In Paper Presented at the Critical Perspectives on Accounting Conference.

Mahoney, L. S., Thorne, L., Cecil, L., \& LaGore, W. (2013). A research note on standalone corporate social responsibility reports: Signaling or greenwashing? Critical Perspectives on Accounting, 24(4-5), 350-359. 
https://doi.org/10.1016/j.cpa.2012.09.008

Maroun, W. (2019). Does external assurance contribute to higher quality integrated reports? Journal of Accounting and Public Policy, 38(4), 106670. https://doi.org/10.1016/j.jaccpubpol.2019.06.002

Michelon, G., Pilonato, S., \& Ricceri, F. (2015). CSR reporting practices and the quality of disclosure: An empirical analysis. Critical Perspectives on Accounting, 33, 59-78. https://doi.org/10.1016/j.cpa.2014.10.003

Nasution, R. M., \& Adhariani, D. (2016). Simbolis Atau Substantif? Analisis Praktik Pelaporan Csr Dan Kualitas Pengungkapan (Symbolic Or Substantive? Analysis Of Csr Reporting Practices And The Quality Of Disclosure). Jurnal Akuntansi Dan Keuangan Indonesia, 13(1), 23-51.

O'Dwyer, B., Owen, D., \& Unerman, J. (2011). Seeking legitimacy for new assurance forms: The case of assurance on sustainability reporting. Accounting, Organizations and Society, 36(1), 31-52. https://doi.org/10.1016/j.aos.2011.01.002

Patten, D. M., \& Zhao, N. (2014). Standalone CSR Reporting by U.S. Retail Companies. Accounting Forum, 38(2), 132-144. https://doi.org/10.1016/j.accfor.2014.01.002

Pemerintah Indonesia. (2007). Undang-Undang Perseroan Terbatas Pasal 40 Tahun 2007. Lembaran RI Tahun 2007 No. 4576. Jakarta: Sekretariat Negara.

Perego, P., \& Kolk, A. (2012). Multinationals' Accountability on Sustainability: The Evolution of Third-party Assurance of Sustainability Reports. Journal of Business Ethics, 110(2).

Rossi, A., \& Tarquinio, L. (2017). An analysis of sustainability report assurance statements: Evidence from Italian listed companies. Managerial Auditing Journal, 32(6), 578-602. https://doi.org/10.1108/MAJ-07-2016-1408

Setiawan, S. R. D. (2019). HM Sampoerna Terima Penghargaan Lingkungan Tingkat Asia. Retrieved April 15, 2019 from https://money.kompas.com/read/2019/06/18/143725926/hm-sampoerna-terimapenghargaan-lingkungan-tingkat-asia.

Suastha, R. D. (2016). Riset Temukan Kualitas CSR Perusahaan Indonesia Rendah. Retrieved April 15, 2019 from https://www.cnnindonesia.com/nasional/20160721074144-20-146030/riset-temukankualitas-csr-perusahaan-indonesia-rendah.

Utama, S. (2011). An evaluation of support infrastructures for corporate responsibility reporting in Indonesia. Asian Business and Management, 10(3), 405-424. https://doi.org/10.1057/abm.2011.10

Voegtlin, C., \& Scherer, A. G. (2017). Responsible Innovation and the Innovation of Responsibility: Governing Sustainable Development in a Globalized World. Journal of Business Ethics, 143, 227-243. https://doi.org/10.1007/s10551-015-2769-z

Wong, R., \& Millington, A. (2014). Corporate social disclosures: A user perspective on assurance. Accounting, Auditing and Accountability Journal, 27(5), 863-887. https://doi.org/10.1108/AAAJ-06-2013-1389

Trihatmoko / Keberlanjutan: Jurnal Manajemen dan Jurnal Akuntansi, 5 (2) 2020, 142-156.
ISSN : 2614-3291 (online) http://dx.doi.org/10.32493/keberlanjutan.v5i2.y2020.p142-156 